ELORE (ISSN 1456-3010), vol. 15 - 1/2008.

Julkaisija: Suomen Kansantietouden Tutkijain Seura ry.

[http://www.elore.fi/arkisto/1_08/leh_b_1_08.pdf]

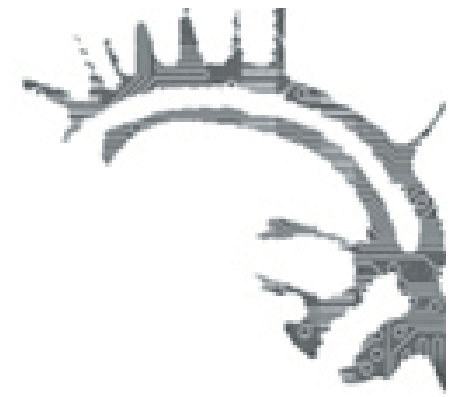

\title{
KiRJA-ARVIO:
}

\section{KOKEMUKSELLISEN FOLKLORISTIIKAN PIONEERI}

Nyqvist, Niklas 2007: Från bondson till folkmusikikon. Otto Andersson och formandet av "finlandssvensk folkmusik". Åbo: Åbo Akademis förlag-Åbo Akademi University Press. 310 sivua, kartta, valokuvia.

\section{$\underline{\text { Outi Lehtipuro }}$}

Istun pienessä tuvassa Vöyrillä kauniina kesäkuun päivänä 1965. Talon isäntä Alfred Backa laulaa: "men akta dig för de böljörna blå, att de ej förråder ditt liv..." Hillitty ja vakava, mutta aivan erityisellä tavalla kajahtava Herr Peders sjöresa tuntui tulevan jostain kaukaa ja kuulen sen korvissani yhä - voi sen kuulla SKS:n äänitearkistossakin. Huomaan odottaneeni Niklas Nyqvistin tutkimusta siitä asti kun vastailmestynyttä kansanrunouden yleisesitystä (Hautala 1963) tenttiin lukiessani opin, että suomenruotsalainen merellinen periferia on keskiaikaisen skandinaavisen balladigenren viimeisiä säilymäalueita, kuten Viena kalevalaisen epiikan. Tai kun joitain vuosia myöhemmin oivalsin, että Åbo Akademin folkloristiikalla (Andersson 1967 ym.; ks. Lehtipuro 1970, 406) on aivan oma tulokulmansa folkloreen ja sen tutkimukseen: runontutkimus on lauluntutkimusta (visforskning), teksti ja melodia kuuluvat yhteen ja laulaja on perinteisen laulurepertoaarin piirissä omia valintojaan tekevä luova yksilö. Saman logiikan mukaan Niklas Nyqvist puhuu Elias Lönnrotin runonkeruusta kiinnostuksena kansanmusiikkiin.

Folkloristiikan suomenruotsalainen ääni sovitettiin naistutkimuksen aikaan kun Ann-Mari Häggman (1992) sijoitti Magdalena-balladin laulajien elämismaailmaan. Se oli ensimmäinen väitöskirja suomenruotsalaisesta kansanmusiikista, jonka keruu oli alkanut 1800-luvun jälkipuoliskolla. Enimmäkseen ruotsinkielisen sivistyneistön ylläpitämän Kalevala \& suomalaisuus -innostuksen vastapainoksi löydettiin sekä suomenruotsalaiset murteet että rannikon talonpoikaisyhteisöjen yhä elinvoimainen soiton ja laulun perinne. Tämän tradition dokumentoijana, elvyttäjänä ja tutkijana Otto Andersson oli kuluneen vuosisadan keskeinen toimija. Polemiikkia herättäneen väitöskirjan Andersson (1923) teki kanteleensukuiseksi arvelemansa jouhikanteleen 


\section{KOKEMUKSELLISEN FOLKLORISTIIKAN PIONEERI}

(stråkharpan) historiasta ja parin vuoden päästä uuteen Åbo Akademihin perustetun musiikkitieteen ja kansanrunoudentutkimuksen professuurin myötä hänestä tuli suomenruotsalaisen kansanmusiikin pitkäaikainen keskushahmo, melkein pyhä lehmä, jonka tekemisiin puuttumisella yhä on rajansa, kuten Nyqvist väitöskirjansa esipuheessa vihjaa.

Tutkijana Otto Andersson kiinnitti ohjelmallisesti huomiota suomalaisen perinteen läntisiin yhteyksiin ja osallistui myös kalevalaista runonlaulua koskeviin keskusteluihin. Kun Niklas Nyqvistin tähtäimessä on nimenomaan suomenruotsalaisen kansanmusiikin kaanon, Anderssonin osallistuminen suomalaisiin keskusteluihin jää kuitenkin varjoon, jatkotutkimusta houkuttelemaan. Jäntevästi kirjoitettuun kirjaan, samoin kuin Otto Anderssonin julkaisuihin kannattaakin paneutua ajatuksen kanssa kaikkien, joita folkloristiikan historia, identiteetti ja sen suomalais-skandinaavinen ääni kiinnostaa. Tarjolla on monia hyviä kysymyksiä ja herkullisia ahaa-elämyksiä. Erityisen askarruttava on autenttisuusdiskurssin (vrt. Bendix 1997) selvästi erilainen paikka suomalaisessa ja suomenruotsalaisessa folkloristiikassa.

\section{ANDERSSONIN ARVOITUS}

Mikä mies, millainen folkloristi ahvenanmaalainen, pelimanninakin kunnostautunut Otto Andersson (1879-1969) oikeastaan oli? Kanttorikoulussa ja musiikkiopistossa saavutettu nuotinnuksen taito ja mentorin Martin Wegeliuksen tuki vei hänet perinteenkeruuseen paitsi ruotsinkielisiin rannikkopitäjiin myös Viron ruotsalaisten pariin. Helsingin yliopistoon hän saapui monivuotisen kenttätyöurakan sekä laajan kirjoitustoiminnan kypsyttämänä, päästen syksyllä 1913, yli 30-vuotiaana, erivapaudella (Kaarle ja Ilmari Krohnin tukemana, ilman ylioppilastutkintoa) opiskelemaan musiikkitiedettä, kansanrunoudentutkimusta ja estetiikkaa.

Ensimmäisen vihjeen miehen laadusta antoi 24-vuotiaan perinteenkerääjän esitelmä (1903) pohjalaisista kansantansseista Svenska litteratursällskapetin vaativalle kuulijakunnalle: Andersson soitti itse viululla näytteensä, sai yleisön huomion ja varmistuksen keruustipendien jatkumiselle.

Nyqvistin silmiin ei näytä sattuneen Bloomingtonin Stith Thompsonin postuumisti julkaistujen muistelmien (1996) eloisa kuvaus hänen suhteestaan suomenruotsalaiseen kollegaan. Osallistujaksi pyydetyn Martti Haavion jäätyä 1950 pois suuresta kansainvälisestä pari viikkoa kestäneestä ja keskustelujen nauhoituksiin perustuvana kirjana (Thompson 1953) kuuluisaksi tulleesta Four Symposia on Folklore-tapaamisesta, Suomea edusti alun perin musiikintutkijoiden kokouksen vuoksi paikalla oleva Otto Andersson, joka muhkeaviiksisenä seuramiehenä nopeasti pääsi kaikkien suosioon.

Isännän mieleen jää Otto Andersson tanssimassa viuluineen ja se, miten hän ekskursiolla, muiden kuljeskellessa hautausmaalla, livahtaa tyhjään kirkkoon urkujen ääreen. Ennen seuraavaa, vuoden 1954 Bloomingtonin tapaamista, Andersson puolestaan toimii tammikuussa 1952 Turussa isäntänä Thompsonin nostalgisella toisella pyhiinvaellusmatkalla folkloristiikan kotimaahan. Antti Aarneen työn jatkaja luennoi 


\section{OUTI LeHTIPURO}

samassa Vanhan Akatemian juhlasalissa, jossa Elias Lönnrot aikanaan oli saanut maisterinpaperinsa. Anderssonin sodanaikaiset natsisympatiat - joihin Nyqvist lyhyesti viittaa - eivät ilmeisesti suhteita haitanneet. Tuskin niistä amerikkalaiset tiesivätkään.

Stith Thompsonin ja hänen vaimonsa päiväkirjat tukevat hyvin Nyqvistin rakentamaa tutkijankuvaa ja todistavat samalla, että 1950-luvulla Otto Andersson oli ehkä meikäläisistä folkloristeista parhaiten uuden amerikkalaistuvan ajan tasalla. Itse asiassa Thompsonin isännöimän tutkijatapaamisen ohjelmaan sisältyvä ajatus (ks. Thompson 1996, 265) folkloristisista intresseistä - tallentaminen, hyödyntäminen, tutkimus - on juuri sama kuin Nyqvistin konstruoima Anderssonin toimintakenttä. Perinteen elvyttämisellä (sovittamisella ja uudelleentulkinnalla) yhteisölliseen käyttöön on sekä Yhdysvalloissa että ruotsinkielisessä Suomessa ollut läpi vuosikymmenten paljon keskeisempi asema kuin "perinteen turmelemista" vierastaneessa suomalaisessa Suomessa. "Ihmeellisellä tavalla aisteihin vetoavan" (Andersson 1905; ks. Nyqvist 2007,124 ) laulun, soiton ja tanssin jatkojalostaminen yhteenkuuluvuuden symboliksi on ollut varmasti paljon hauskempi ja laajempiin piireihin aidosti vetoava hanke kuin Kalevalan luettaminen.

\section{MINKÄ NUORENA OPPII...}

Vaikuttavinta Nyqvistin konstruktiossa on Otto Anderssonin uran pitkäjänteisyys, jota tuki varakas vaimo ja laivanvarustajaserkun lahjoituksen mahdollistama professuuri: hän sai vapaasti tehdä juuri sen, minkä näki oikeaksi ja tarpeelliseksi, liikkua polskasta ja balladista Sibeliukseen ja takaisin, olla sekä tutkija että poleemikko, popularisoija ja soveltaja, kansanmusiikkikaanonin rakentaja. Nuoruuden kokemus talonpoikaishäistä maalaisyhteiskunnan musiikillis-kulttuurisen ilmaisun fokuksena näkyy yhä siinä, että "suomenruotsalaisten SKVR:ssa" Bröllopsmusik on kontekstuaalisesti omana niteenään. Finlands svenska folkdiktning-ainesjulkaisun yleislinjassa "kansallista" suomenruotsalaisuutta tavoitteleva ideologia kuitenkin voitti kontekstuaalisuuden: paikallinen omaleimaisuus häviää ja taitajien repertoaarit hajoavat, vaikka etenkin soittajien näkyväksi tekijänä Andersson kameroineen jo varhain uurasti. Tämä on ehjän tutkijakuvan särö, paradoksi, menetetty mahdollisuus (jonka aineistojen digitointi kuitenkin voi tuoda takaisin).

Täsmälleen sama dekontekstualisointi tapahtui myös SKVR-prosessissa, joka puolestaan pilkkoi ja nimesi lauluperinteen luonnolliset kokonaisuudet Kalevalan mukaan. Moni asia Anderssonin tekemisissä tuntuukin selittyvän paitsi skandinaavisen myös suomenkielisen kansanrunousaktiviteetin paralleelina, joskus haastajanakin. "Vanha ja aito" voitti uuden ja tulossa olevan, polska valssin, viulu haitarin, lähes kadonneen oletetun runon fragmentti populaarin uudemman kansanlaulun.

Ei voi olla kysymättä, olisiko Otto Andersson ilman krohnilaista koulutustaan ollut loppuun asti, myös tieteessä, uskollisempi itselleen ja omalle kokemukselleen. Ajatusleikkiä voi jatkaa: olisiko Anderssonin ja parikymmentä vuotta nuorempien Martti Haavion ja Elsa Enäjärvi-Haavion intensiivisempi keskusteluyhteys voinut 


\section{KOKEMUKSELLISEN FOLKLORISTIIKAN PIONEERI}

johtaa humanistisen kontekstualismin murtautumiseen suomalaiseen folkloristiikkaan jo ennen sotia ja sosiologian tuloa. Heissä kaikissa nimittäin kyti jonkinlainen kapina krohnilaisuutta vastaan. Kuten Andersson tunsi kansanmusiikin pelimannin ja laulajan kannalta, Haavio pystyi eläytymään runon maailmaan P. Mustapäänä. Puhuivatko nuo Krohnin oppilaat keskenään vai pitikö kieliriita ja ikäero heidät erossa toisistaan?

Elsa Enäjärveä kuten Anderssoniakin anglosaksinen maailma selvästi viehätti, ja hänen intressinsä esteettisessä kokemuksellisuudessa, kiinnostuksessa laulutapoihin ja Ritvalan helkajuhlaan sekä traditiota yllä pitäneisiin laulajiin on paljon yhteistä Otto Anderssonin, samoin kuin kansankulttuurin kokonaisuutta silmällä pitäneen Kustaa Vilkunan kanssa. Yhteisistä intresseistä ja sympatiasta todistaa myös tapaaminen Turussa lokakuussa 1926 sekä Elsan osallistuminen muutamaa vuotta myöhemmin Anderssonin juhlakirjaan, kuten Katarina Eskolan (1999, 487; 2000, 126) julkaisema kirjeenvaihto kertoo. Johtiko juuri tämä yhteys tutkijan helkavirsien kimppuun: olihan Ritvalan "epäkalevalaisilla" (ja sellaisina melko tuntemattomiksi jääneillä) runoilla juurensa juuri siinä keskiajalta juontuvassa balladitraditiossa, jonka vahvan suomenruotsalaisen edustuksen ennen muuta Andersson ja hänen kenttätyötään 1920-luvulla jatkaneet Greta Dahlstöm ja Alfhild Forslin olivat tehneet näkyväksi (ks. Andersson 1934). Olisiko tämä linkki postuumisti ilmestyneen Ritvalan helkajublan (1953) viitteissä paremmin esillä, jos Elsa Enäjärvi-Haavio itse olisi voinut teoksensa viimeistellä?

Otto Andersson oli, kuten tutkijansa Niklas Nyqvist, monipuolisesti aktiivinen muusikko. Läpi vuosikymmenien hän puolusti, kuten nyttemmin Heikki Laitinen, musiikin ja laulun merkitystä sekä yksittäisille ihmisille että koko yhteiskunnalle. Jo nuorena hän sisäisti oman aikansa ja ympäristönsä unelman, tehdä Suomen ruotsalainen kansanosa näkyväksi paitsi kielellisesti myös kulttuurisesti omaleimaisena kokonaisuutena. Tätä kirjoittaessani Kalevalanpäivän aaton Hufvudstadsbladet (27.2.2008) kertoo, kuin pisteeksi i:n päälle, miten uudessa Norden $i$ dans -teoksessa suomalainen ja ruotsalainen Suomi esiintyvät kahtena erillisenä maana, jotka kumpikin saavat yhtä paljon tilaa. Voin kuvitella millainen pilke silmäkulmassaan Andersson valkoisine viiksineen katselisi 2000-luvun kansanmusiikkiharrastuksesta kertovaa koko sivun artikkelia, jossa hänen ideastaan kehkeytynyt 1906 perustettu Brage-seurakin mainitaan ja jossa iloinen tanssijoiden ryhmä poseeraa kansallispuvuissaan. Kun sama lehti muutamaa päivää myöhemmin kertoo amatöörikuorojen pitkäaikaisesta valmentautumisesta pääsiäisajan tärkeään Händelin Messiaan esitykseen, tuntuu Otto Anderssonin henki leijailevan senkin hankkeen päällä, samoin kuin Nyqvistin kertoman mukaan hänen työpaikallaan Turun Sibelius-museossa.

\section{KirjallisuUs}

ANDERSSON, OT'TO 1923: Stråkharpan. En studie i Nordisk instrumenthistoria. Helsingfors: Holger Schildts tryckeri.

— (utg.) 1934: Finlands svenska folkdiktning. V Folkvisor. 1. Den äldre folkvisan. Skrifter 


\section{OUTI LeHTIPURO}

utgivna av Svenska litteratursällskapet CCXLVI. Helsingfors: Svenska litteratursällskapet i Finlands förlag.

— 1967: Finländsk folklore. Åbo: Åttas förlag.

BAKKA, EGIL \& BISKOP, GUNNEL (red.) 2007: Norden $i$ dans. Folk - Fag - Forskning. Norge: Novus forlag.

BENDIX, REGINA 1997: In Search of Authenticity. The Formation of Folklore Studies. Madison, Wisconsin: The University of Wisconsin Press.

ENÄJÄRVI-HAAVIO, ELSA 1953: Ritvalan helkajubla. Jälkeenjääneen käsikirjoituksen täydentänyt ja painoon toimittanut Martti Haavio. Porvoo: WSOY.

ESKOLA, KATARINA (toim.) 1999: Kahden. Martti Haavion ja Elsa Enäjärven päiväkirjat ja kirjeet 1920-1927. Porvoo: WSOY.

— (toim.) 2000: Yhdessä. Martti Haavion ja Elsa Enäjärven päiuäkirjatja kirjeet 1928-1939. Porvoo: WSOY.

HAUTALA, JOUKO 1963: Suomen ruotsinkielinen kansanrunous. - Matti Kuusi (toim.), Suomen kirjallisuus I. Kirjoittamaton kirjallisuus. Helsinki: Suomalaisen Kirjallisuuden Seura ja Otava.

HÄGGMAN, ANN-MARI 1992: Magdalena på källebro. En studie i finlandssvensk vistradition med utgangspunkt $i$ visan om Maria Magdalena. Helsingfors: Svenska litteratursällskapet i Finland.

LEHTIPURO, OUTI 1970: Näkymiä 1960-luvun folkloristiikkaan. - Virittäjä 3.

THOMPSON, STITH (ed.) 1953: Four Symposia on Folklore. Indiana University Publications, Folklore Series no. 8. Bloomington: Indiana University Press.

- 1996: A Folklorist's Progress. Reflections of a Scholar's Life. Edited by John McDowell, Inta Gale Carpenter, Donald Braid, Erika Peterson-Veath. Special Publications of the Folklore Institute No. 5. Bloomington: Indiana University.

Filosofian lisensiaatti Outi Lehtipuro on joensuulainen folkloristiikan tutkija. 